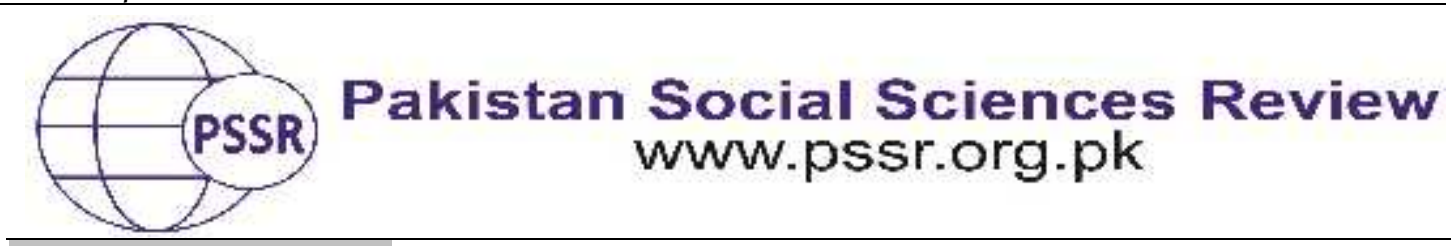

RESEARCH PAPER

\title{
Website Homepages of Private Universities of Pakistan Serving as Bait for Prospective Students: A Critical Discourse Analysis
}

\author{
Dr. Syed Shujaat Ali ${ }^{1}$ Tariq Amin ${ }^{2}$ Muhammad Shahid ${ }^{3}$
}

1. Chairman, Department of English, Kohat University of Science \& Technology, Kohat, KP, Pakistan

2. M. Phil Research Scholar, Department of English, National University of Modern Languages, Islamabad, Pakistan

3. Lecturer, Department of English, University of Malakand, KP, Pakistan

\begin{tabular}{|c|c|}
\hline PAF & A \\
\hline $\begin{array}{l}\text { Acc } \\
\text { Aug } \\
\text { On }\end{array}$ & $\begin{array}{l}\text { This study mainly focused on the use of language and pictur } \\
\text { in website homepages and strategies employed by } t \\
\text { universities to manipulate and influence their visitors. Thr } \\
\text { private universities were selected for the study by using simp } \\
\text { random sampling technique. From the website homepages }\end{array}$ \\
\hline $\begin{array}{l}\text { Discourse } \\
\text { ge, } \\
\text { g, } \\
\text { alyzing, } \\
\text { ges }\end{array}$ & $\begin{array}{l}\text { university were selected by us } \\
\text { technique. Fairclough's three-din } \\
\text { the analysis of these screenshot } \\
\text { private universities use differe } \\
\text { strategies to manipulate and ir } \\
\text { influence them to give preferer }\end{array}$ \\
\hline nding & $\begin{array}{l}\text { these universities rely on pictures of young beautiful } \\
\text { ales, majestic buildings, and ideologically loaded language } \\
\text { attracting students to take admission in them. The websites } \\
\text { private universities make a calculated choice of pictures, } \\
\text { abulary and grammar for loading them with their implicit } \\
\text { ologies, which are taken for granted by prospective students } \\
\text { common sense assumptions. In this way, they or their }\end{array}$ \\
\hline oo.com & $\begin{array}{l}\text { hem, are } \\
\text {, without } \\
\text { ties }\end{array}$ \\
\hline
\end{tabular}

\section{Introduction}

Due to growing dependence on internet, different organizations offer their services online. To offer their services in an attractive and persuasive manner, organizations have started giving importance to advertising of their services. To cater to the demands of these organizations certain agencies specializing in online 
advertising have cropped up. Advertising is a vast field which takes into consideration all those motivating factors that direct human behavior. Different educational organizations also benefit from this science of advertising and promote their business by framing their advertisements in accordance with the age, psyche, requirements, limitations and wishes of their target recipients. These organizations manipulate the prospective customers very effectively because people, due to hectic schedules and traffic problem, also prefer administering their affairs through internet. Internet has placed almost all national and international educational organizations in any corner of the globe at the distance of a single click. Sitting in their homes, young students and their parents use internet for searching educational organizations, their educational programs, faculty, fee-structures, work environment, and admission criteria. All universities have their own websites that provide comprehensive and detailed information about different features of the universities. These universities know their target customers and tailor their advertisements in such a way that they can convert maximum number of website visitors into their prospective students. The website homepages comprise pictures normally highlighting pretty young female students wearing fashionable dresses, attractive buildings and modern sophisticated equipment for convincing their prospective students about their high standard of education and the level of trust people can put in them, state-of- the-art classrooms with stately audio visual aids, big green lawns indicating an invigorating environment, without mere confinement to the classrooms, academic discussions with smiling faces between students of opposite genders indicating ease, and enjoyment, besides indicating a place one can come into contact with opposite gender students of high family and enjoy their company, pictures of convocation showing students going ecstatic over getting their degrees, thereby shifting attention of the students immediately towards the prize they are going to win soon. The visitors' decision to select or reject a university depends on the websites of the university. These pictures influence the visitors and make them go for a specific university. There are always hidden ideologies behind the use of such pictures, videos, and graphics in the design of website homepages of the private universities. The study in hand critically analyses the website homepages of the private universities of Pakistan.

\section{Literature Review}

\section{Website Homepages}

A start page or a home page is the main or the initial webpage of a browser or a website. A home page is generally the main page that visitors navigating to a website from a web search engine will see. The private universities of Pakistan try to design their homepages beautifully and make them more and more visible and catchy. By using pictures and some other effects, the websites are used by universities to brand themselves. Website homepages serve as landing pages to attract visitors. One can navigate from the homepage to other pages on the site through links. Bonardel, Piolat and Begot (2011) say that the users' first impressions 
when they land on a site determine whether or not they stay on it. According to Weideman (2013), the visibility of a Web page plays a role in attracting potential clients, as more and more young users are depending on the Web for their everyday information needs. The websites developers are asked by the universities to design such homepage for the university that works with high speed and that is attractive. If the website does not respond and takes time in responding, people usually quit using it and search for other university' s website and as result, the university loses a chance to attract the potential visitor. Weinberg (2000) says that when the loading time of a homepage exceeds the maximum amount of time that a web user is willing to wait, a web user will either redirect the web-browser to an alternative (e.g., competitor's) website or quit using the web and as a result, an opportunity is lost to not only influence, serve, or interact with a potential customer, but also to advance the growth of e-commerce.

\section{Critical Discourse Analysis}

Critical discourse analysis is a critical study in which power is identified, exposed and challenged. Van Dijk (1985) says that there exist connections between power and discourse in Critical discourse analysis (CDA). Fairclough (1992) says that there is a dialectic relationship between discourse and social structures. He says that the social structures, institutional structures, and discourse structures influence the discourse practice and, in return, get reshaped by the discourses practices. It means that language is powerful and it is used to manifest ideologies. There are always ideologies behind the use of language. These ideologies direct people's behavior ideally as long as they are implicit, because when the manipulating aspect of an ideology becomes known then it ceases to remain an ideology loses its capacity to exercise power.

Turhan (2017) says that the way how people interpret messages transmitted through language can be easily directed towards what is aimed to be transmitted. Wodak (1996) says that the term discourse includes all forms of language, such as written, spoken, and even visual tests. In all these forms, vocabulary and grammatical items are not randomly selected; rather all of them are chosen on an ideological basis because language is the tool which transmits socially negotiated issues to people in a society. Fowler et al. (1979) points out that the choice of grammar and vocabulary for subjects is not arbitrary but ideologically based. There are always ideologies behind messages that are transmitted. Halliday (1994) also subscribes to the relation between society and discourse. He believes that language is "social act." Faircolugh (1992) also believes that language is a social practice, implying that whenever language is used, it is used by keeping in mind the existing social rules, institutional rules and discourse rules and this product of the process of discourse, i.e. text, is interpreted in accordance with the social rules, institutional rules and discourse rules.

As said before, when people use language, they use it by taking into account the already established structures which are imposed not only upon the individual 
producers of language, but also upon language interpreters. Certain assumptions are taken for granted by the text producers and text interpreters. Fairclough (1992) says that certain discourse practices become common sense after the process of naturalization and, then, people take them for granted. These practices have an ideological effect behind them. People are usually unaware of the hidden ideologies that are working. When people come across an advertisement, they accept it blindly and do not think over it and take things for granted because these assumptions and expectations have become common sense after the process of naturalization.

Critical Discourse Analysis is used to identify the hidden ideologies that work behind the discourse practices. After identifying the ideologies, these are exposed to the public in order to make them aware of the power that is exercised by the implicit ideologies of the people in power. This implicit power is then challenged and changed. Lots of writers have used this critical discourse analysis model in the analysis of advertisements, speeches and debates but no one, as per my information is concerned, has critically analyzed the website homepages of any university or college. The current study is going to fill this gap. Pakistani private universities impress people through their website homepages via language, pictures of girls and pictures of beautiful buildings in the website homepage and finally take admission in that university. The current study is going to critically analyze the website homepages of selected private universities of Pakistan.

\section{Material and Methods}

For this study, qualitative approach was preferred over the quantitative approach as it seeks to investigate and explore how the different private universities of Pakistan use different discursive techniques and strategies to impress, manipulate and make the visitors give preference to their university over other universities and take admission in the university.

In Pakistan, there are 69 HEC recognized private universities which are arranged in alphabetical order. Each university was given a number such as 1, 2, 3 etc and 3 universities were selected through fishbowl draw technique- a technique in simple random sampling method. The universities selected were Lahore Leads University, The University of Lahore and Abasyn University, Peshawar. Twenty screenshots were taken from the websites of each university, out of which 3 screenshots per university were selected by using simple random sampling technique via. Fishbowl draws technique. The screenshots were analyzed by using Fairclough's (1992) three stage model.

In the present study, Fairclough's (1992) three dimensional model was employed for the analysis of the website homepages of the private universities of Pakistan. In this model, there are three dimensions/stages which are closely related to one another. These are 1) description of the text, 2) interpretation of the process of production and process of interpretation, and 3) explanation of the social conditions, institutional conditions and situational conditions which affect the process of 
production and process of interpretation. These three stages are given in the figure 1 below:

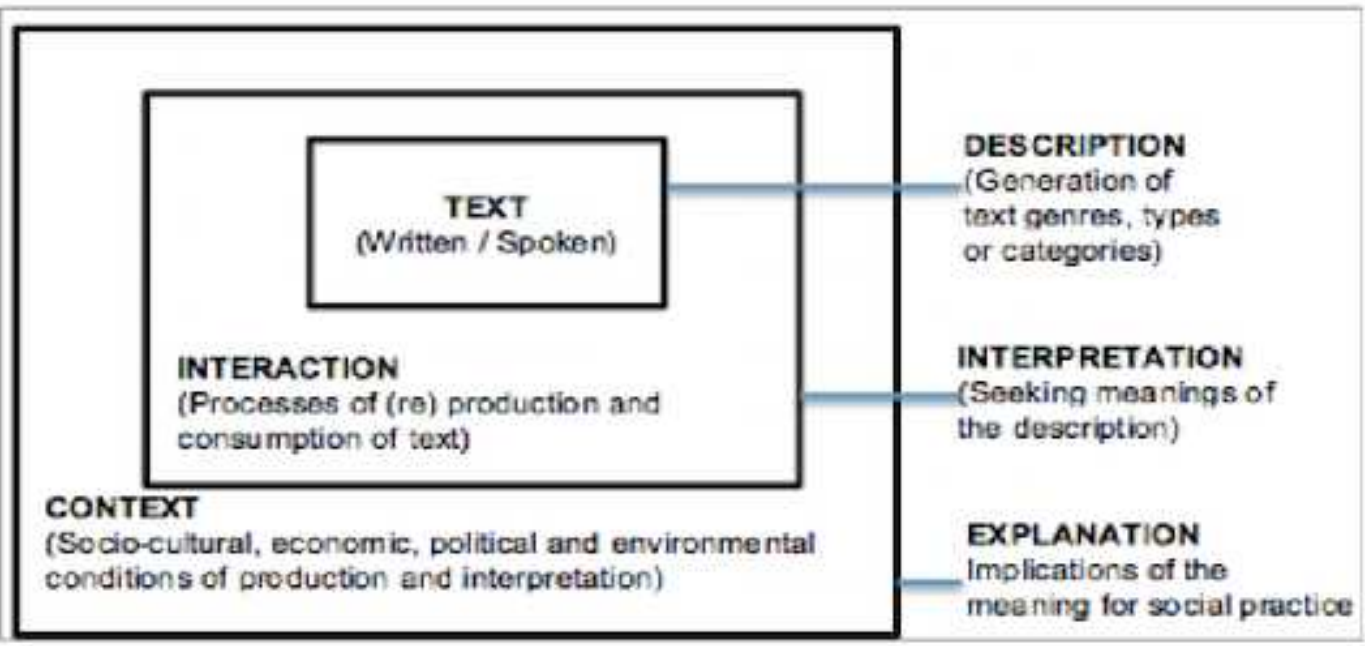

Figure 1. Fairclough's three dimensional model of discourse analysis (1992, p.25)

In the first stage of the analysis, the verbal or visual text or both are described. The word "text" represents not only linguistic features such as words and sentence structures but also sounds, videos, colors, images and so on. The second stage is about the interpretation of how a text is produced and how it is interpreted by the audience. In the third stage, the text production and interpretation are linked to social, institutional, and discourse structures that affect them.

\section{Results and Discussion}

\section{The University of Lahore}

This is a university located in Lahore, Pakistan, offering undergraduate, postgraduate and doctoral admissions. Three Screenshots are selected for analysis.

\section{Screenshot 1}

In the below university website, homepage screenshot shows three female students without any male student, taught by a young male teacher, clearly implying that females are used as objects to attract other students. The university could have given a male student among these female students as well, but they did not give even a single male student in the picture. There is a specific purpose behind this. In the picture, it can be seen that the teacher is teaching students the human brain. Through this the university wants to show its technological equipment. It wants to show that the university is fully equipped with the latest technology.In the left corner of the picture, the logo of the university can be seen. The logo of the university contains a well known and famous place of Pakistan, i.e. Minar-e- 
Pakistan. All Pakistani citizens like this most famous historical place. Instead of these pictures and verbal words, the university could have used other pictures and words but the university has used these pictures and words because there are hidden ideologies behind their use.

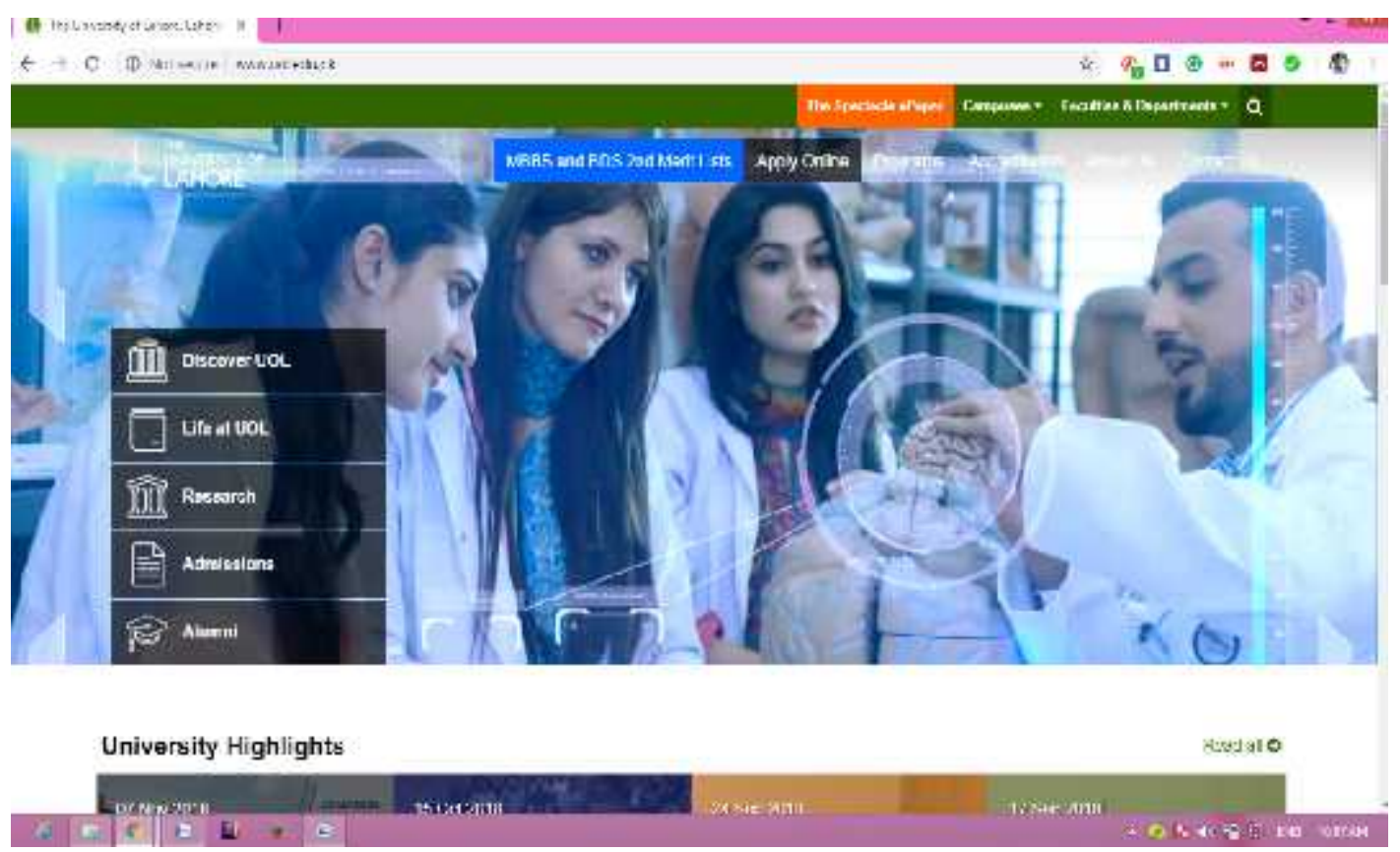

\section{Screenshot 2}

The second selected Screenshot gives the outside view of the entire university. It seems that the picture has been taken somewhere from the sky through drone camera. The university has got very beautiful building and surroundings. The environment of the surroundings seems very clean. Trees are there. Masjid and lawn are there in the university. The picture attracts the students who visit the webpage of the university. Religious people are attracted by it as the picture is taken from the side where there is mosque. Along with religious minded students, students who usually take admissions for entertainment purposes also find the university interesting. On the above side of the screenshot, MBBS and BDS are written and they are highlighted. When one just land at the webpage, his/her attention instantly goes to the highlighted MBBS and BDS. The university offers many undergraduate and post graduate degrees but they have written just these two degrees on the homepage. They have done so because these degrees are considered to be the most prestigious degrees and students find it difficult to take admission in such degrees that is why the universities has written it on the homepage and highlighted it to attract students towards the university. On the one side, the university has given such pictures to give the impression that the university environment is kept clean 
and beautiful for the students, on the other hand, they have implicit ideologies behind it. They want to make students take join the university.

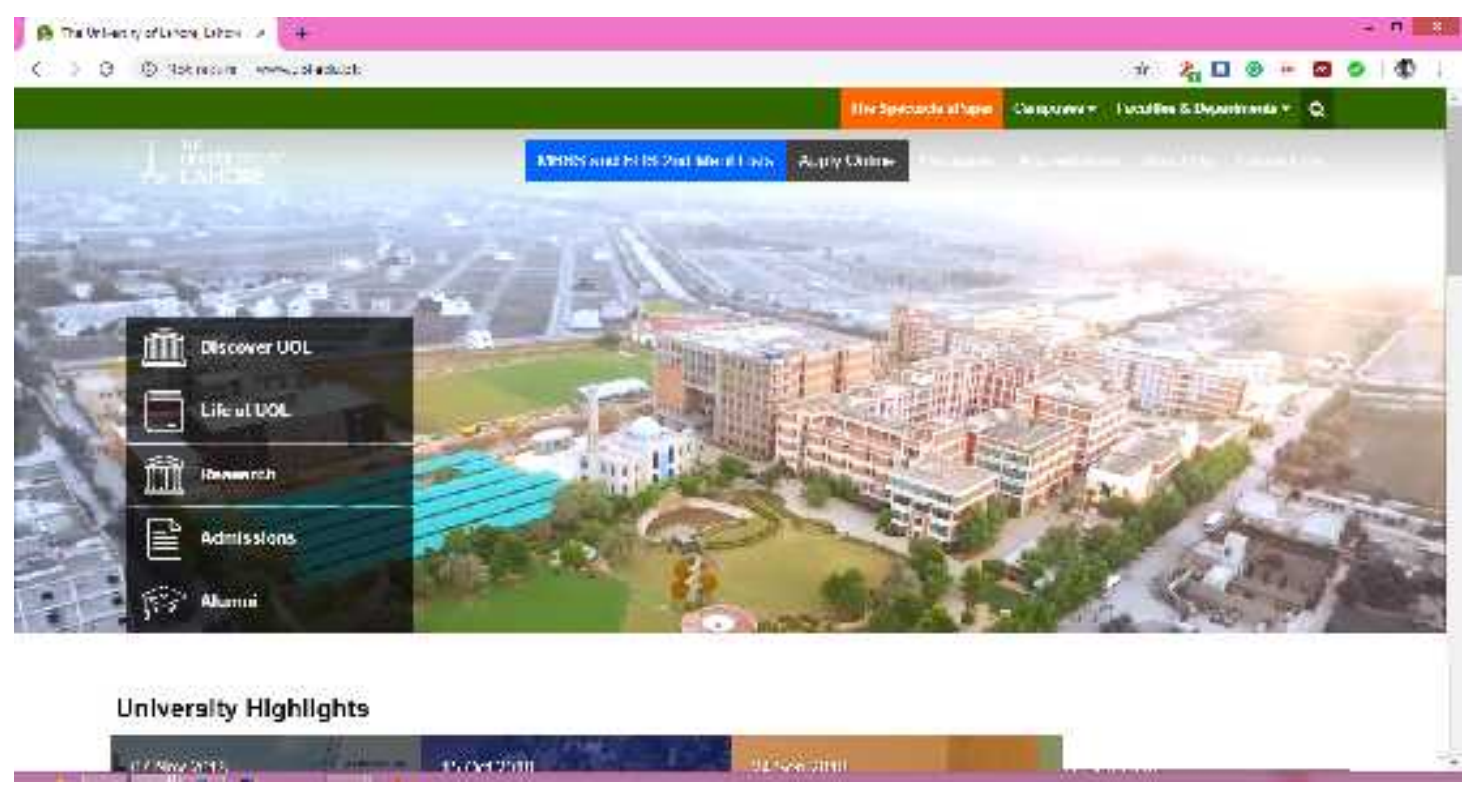

\section{Screenshot 3}

Parents want their children to study in an organization that has internationally acknowledged status and that is preferred by international students. In the same way, every student wishes to study in an institution and organization where he/she can have interaction with foreign students. In Pakistan, mostly students face problems in learning English language that is why students prefer university having foreign students with whom they can interact and improve their language. In the website homepage of the University of Lahore, the international student can be seen. There are implicit ideologies behind using this picture. It is not selected randomly. Fowler et al. (1979) points out that the choice of grammar and vocabulary for subjects is not arbitrary but ideologically based. The words "International Students" are written there and their font size is larger than the font size of the below sentences. It directly catches the attention of the students who visit the website of the university. The university has written the name of the countries whose students are studying at the University of Lahore. Some of the countries are Palestine, Yemen, Sudan, Syria, Somalia, Afghanistan, Nepal, Oman, Kingdom of Saudi Arabia, South Korea, Jordan, UAE and Uganda etc. The university wants to get the attention of the visitors through mentioning international students. In the same picture, some females can be seen behind that also adds to the achievement of the hidden objectives of the university. 

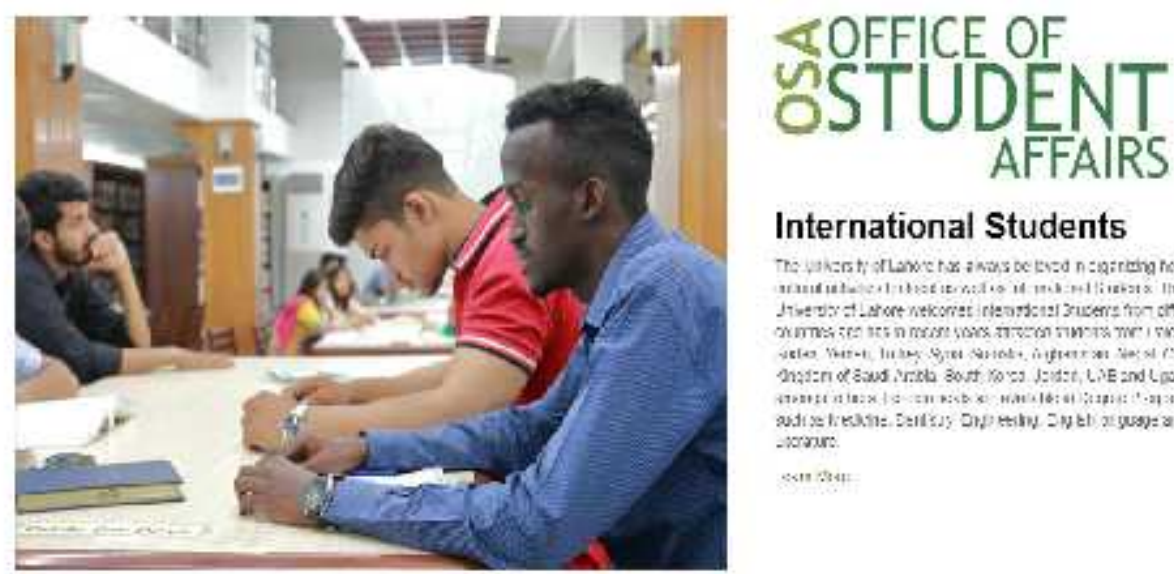

\section{International Students}

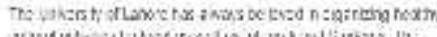

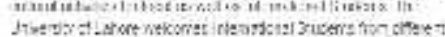

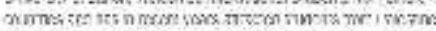

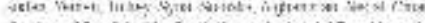

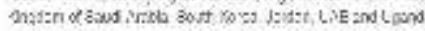
ה十⿵冂卄

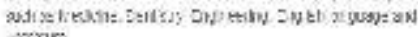
- worour:

set thest

\section{Absyn University, Peshawar}

Abasyn University is one of the famous private universities located at Peshawar, Khyber Pakhtunkhwa, Pakistan. It offers both undergraduate and post graduate degrees. Three screenshots taken from the website homepage of the university are analysed below.

\section{Screenshot 1}

By looking at the picture at first glance, the first thing that catches the attention of the visitor is the sentence written exactly in the centre of the picture, i.e. "the trusted name in higher education". Many government sector, public sector and private universities are there that provides higher education. But the university says that they are the most trusted in providing higher education. Everyone looks for an organization that is trusted the more as compared to other universities. Here in this sentence, the university intends to show its superiority over other universities. It shows that the university is superior to other university in terms of the trust of the public over the university. On the right side of the picture, "passion to design futures" is written and it has also an impact on the visitors. Students thin that the university is really interested in designing the futures of the students and it is not interested in anything else. What they are actually concerned is the design of the futures of the students. In reality, the university wants the visitors to get influenced by such strategic use of language and take admission in the university. 


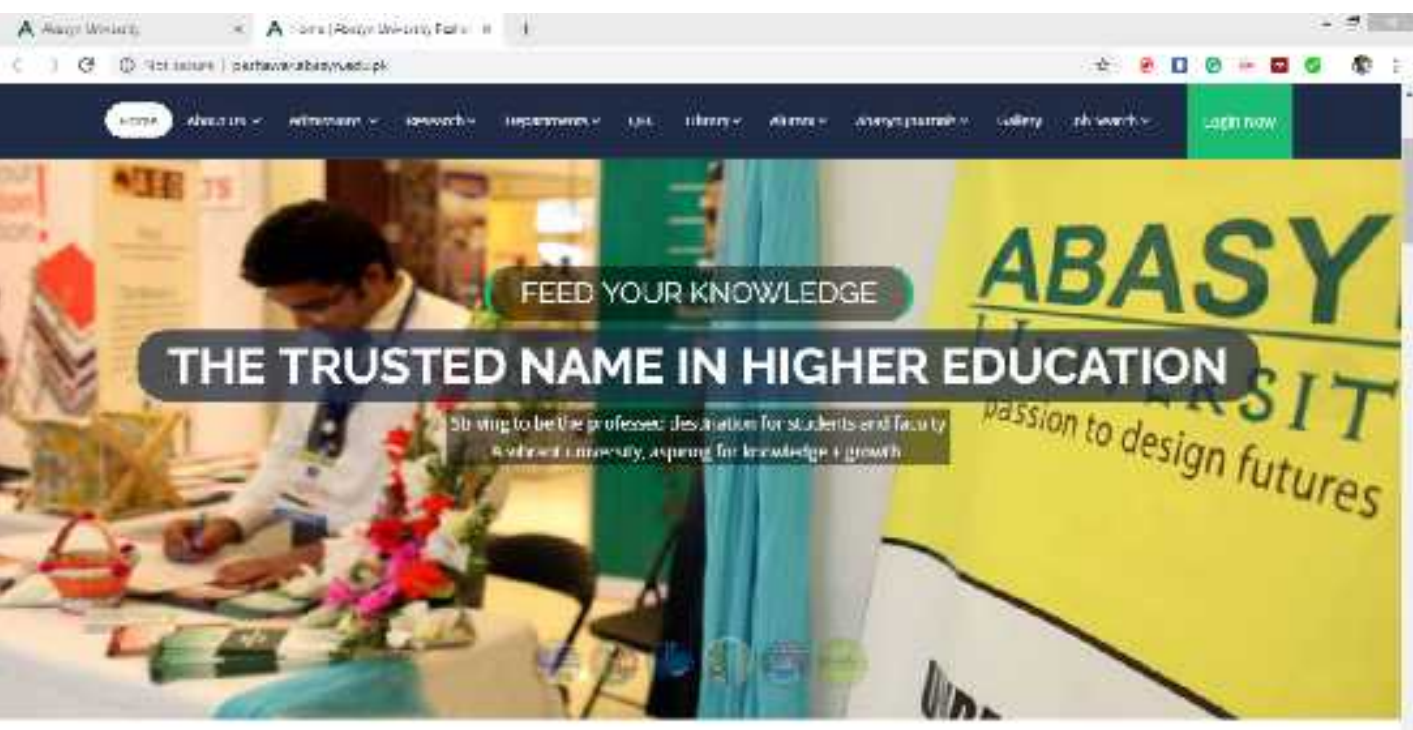

\section{Screenshot 2}

In this screenshot, two things are noticeable. One is the building that is on the left side of the picture. This is a beautiful building. When one visits the website of the university, he/she directly looks at the buildings of the university. People are interested in the beautiful and clean buildings as well and they prefer universities having well decorated buildings. In pictures, it can be seen that all females are there in the picture and no male student is there. These pictures are not selected randomly. Rather they are selected for performing a specific purpose. There are implicit ideologies behind the selection of such pictures for the website homepage of the university. Like students, some of the parents also want their children to go to a university where there is co-education. It is observed that the website homepages are usually full of pictures of females that indicate that the university is offers coeducation and students go for that university.

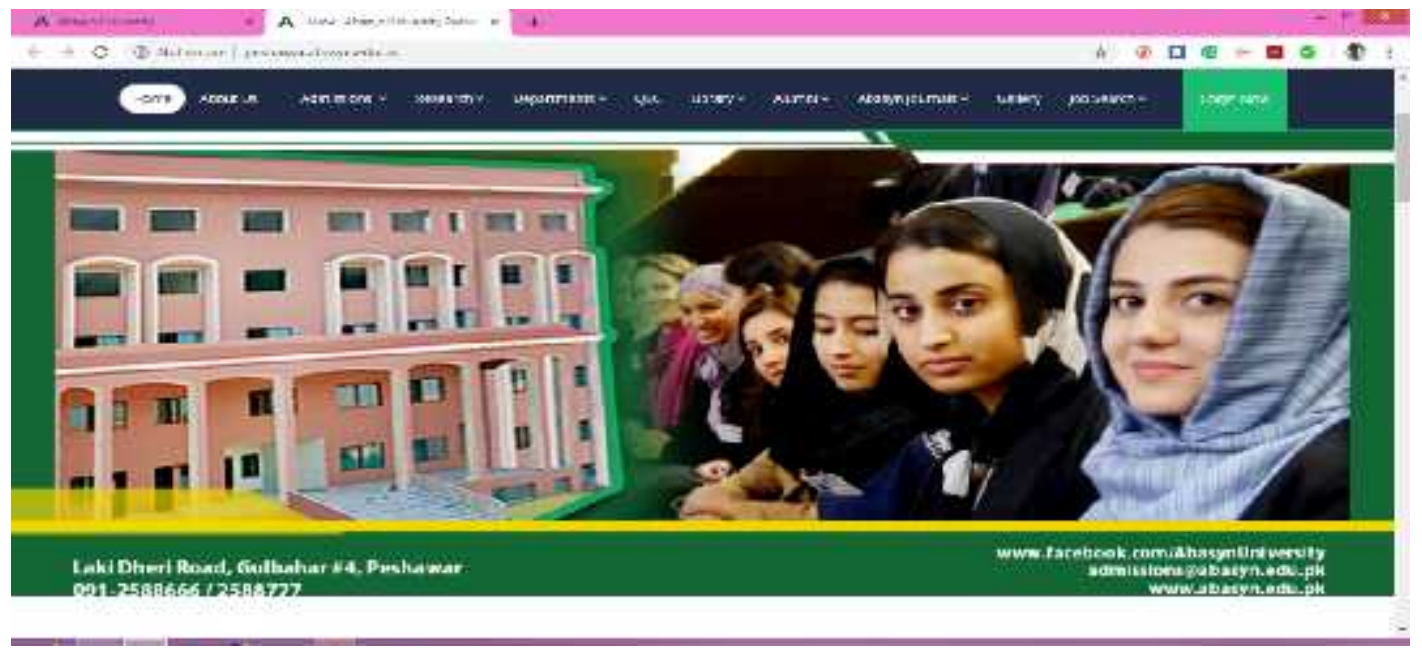




\section{Screenshot 3}

The picture is the $2^{\text {nd }}$ convocation of the Abasyn University, Peshawar. The governor of Khyber Pakhtunkhwa is there in the picture and some other university professors are also there with him. The university has given the picture of the convocation in their website homepage. They might to prove that the university is HEC recognized university because most of the people usually have doubts on the status of the university. Some universities are not HEC recognized. The picture is given to prove that the university is HEC recognised and students can join it. "Striving for your better future" is written just below $2^{\text {nd }}$ convocation. This technology is adopted by many organizations, institution and beauty product companies to persuade the public. The second person pronoun "your" is used to show that we are working just for your better future and we do not have any other intentions other than striving for your better future. People get influenced by the persuasive use of the language and they go for the university.

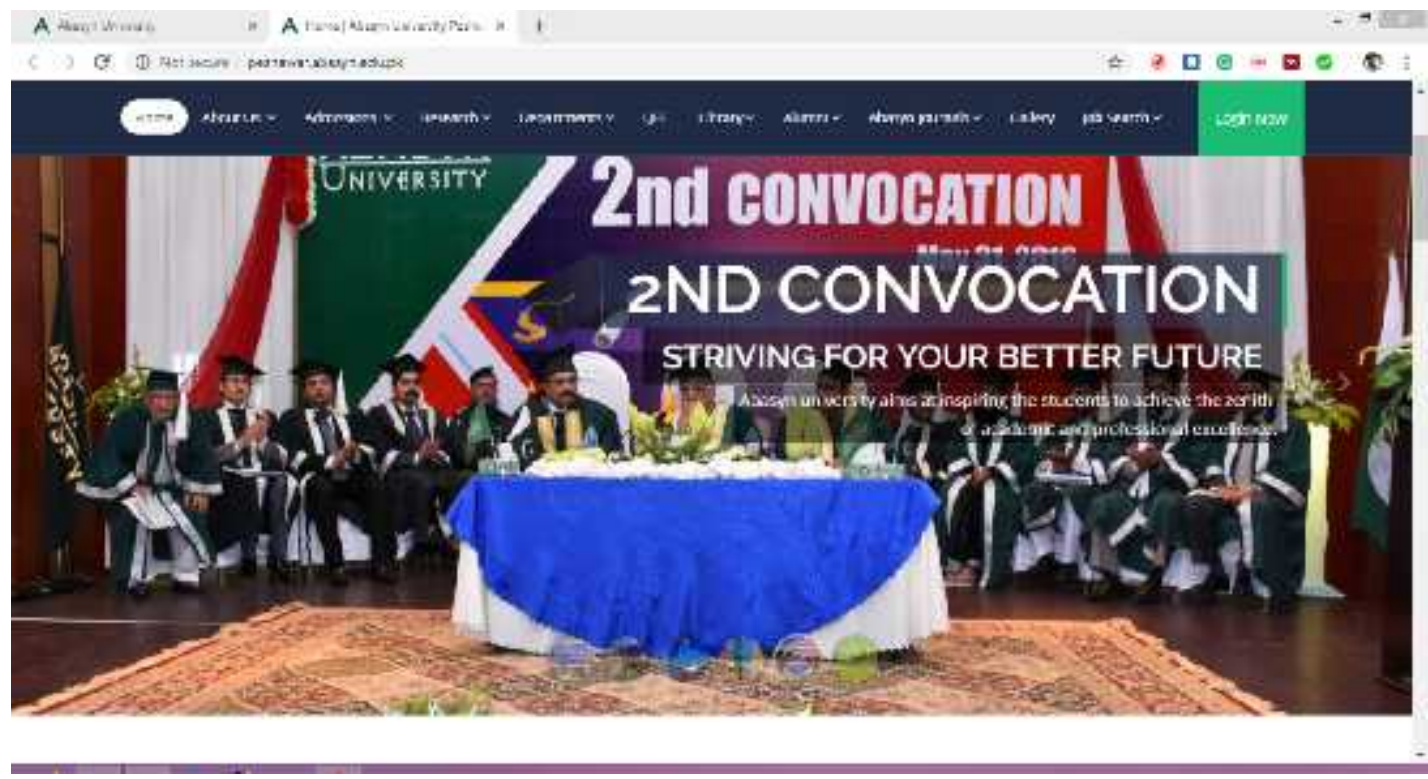

\section{Lahore Leads University}

Lahore Leads University is one of the leading universities in higher education located in Lahore. Like the above universities, Lahore Leads University also provides admission in undergraduate and postgraduate degrees.

\section{Screenshot 1}

The convocation of a university shows that the university is HEC recognized university and students can take admission without any fear and that is why most of the universities give the picture of the convocation in their website homepages. Like other universities, this university has also given picture that contains mostly females. The universities select such pictures because they want to achieve hidden objective 
through them. In the picture, "ask a question" can be seen on the right bottom. The university provides this facility and it provides instant replies. On one side, it is helpful for the people who visit the website of the university and they can take instant help from the university officials through this facility. On the other hand, the university might have created this facility to convince the people through this facility. They provide immediate feedback so that they can engage the visitors in conversation and can convince them.

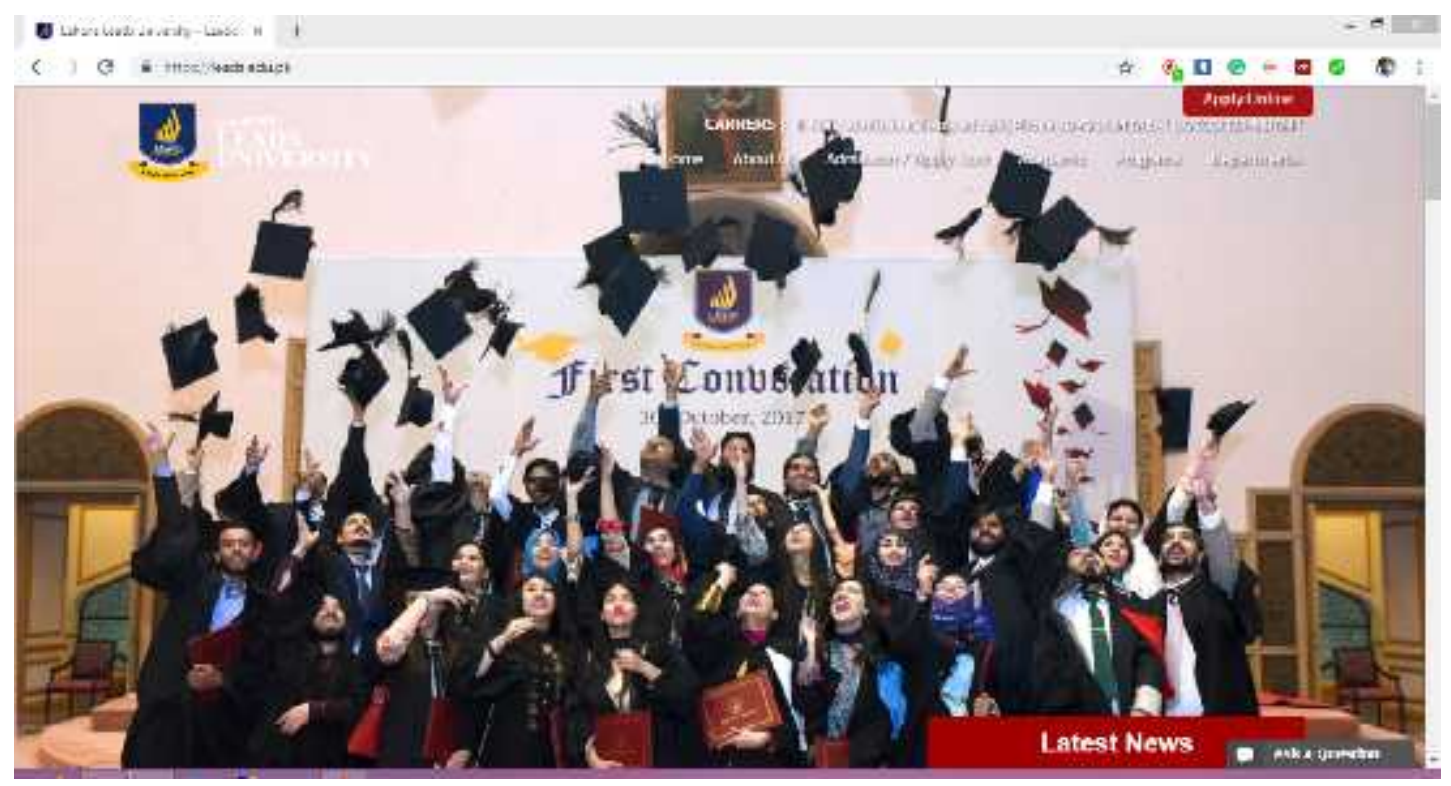

\section{Screenshot 2}

Most of the students try to secure admission in a university which offer more and more scholarships because mostly students have got financial problems. When students visit a university website, they look for something written about the scholarships that the university offers. In the website of the Lahore Leads University, the university has written about the Need Based Scholarship and Merit Based Scholarship. It is written on the front page of the university so that it can attract the students.The other facilities provided by the university are also given there. Some of the basic facilities are cafeteria, computer lab, library and sports club etc. These are the facilities that students usually need in the university. By writing about the basic facilities in the website homepage, the university wants to show that the university is the best amongst the private universities and it can be the best possible university for the students to take admission in. In the background of this information, different stalls and buildings are there that also shows that the university has got good buildings and students can enjoy in funfair programs. 

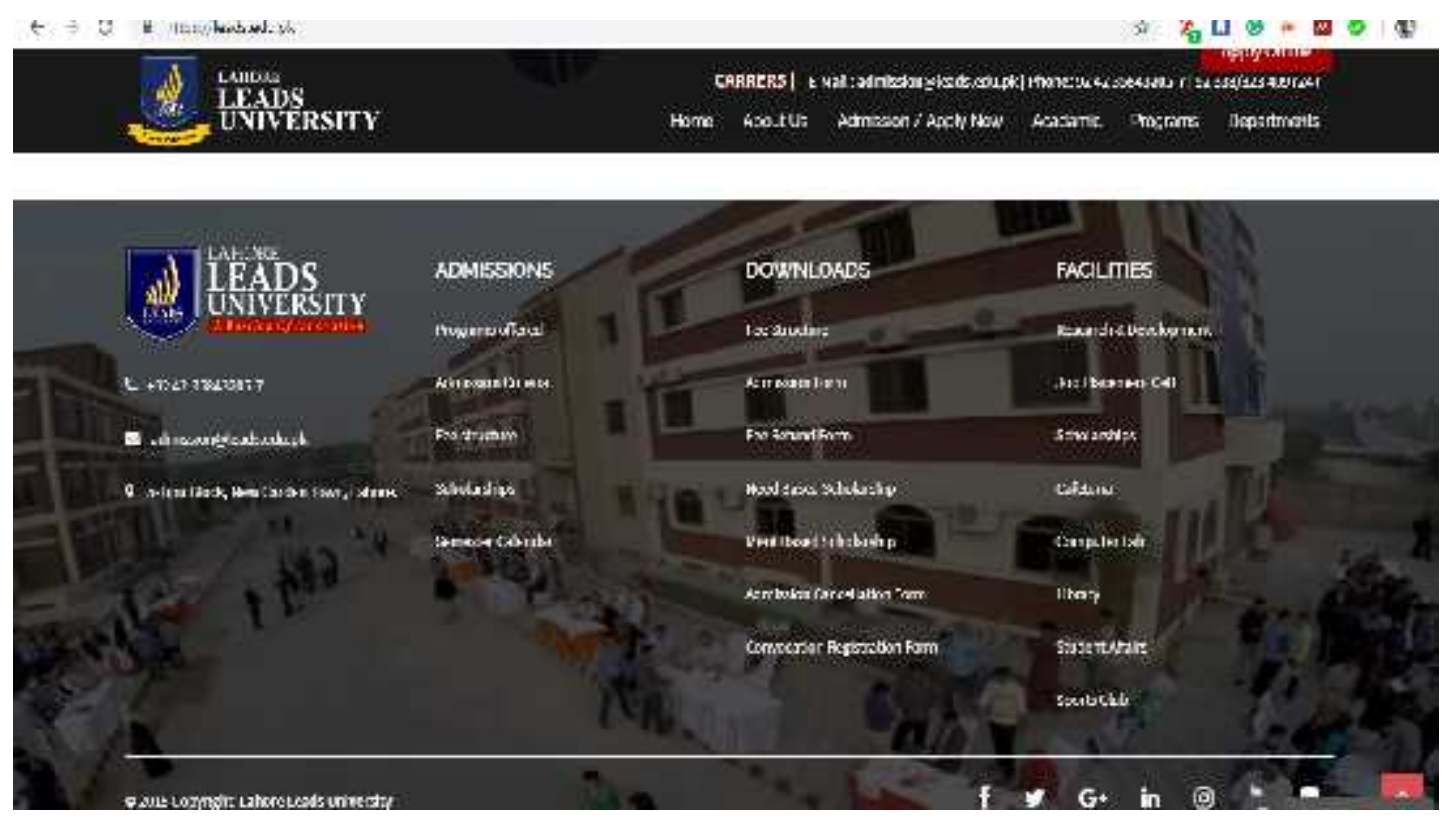

\section{Screenshot 3}

This picture is the picture of the second convocation 2018 of the Lahore leads university. This picture is the most attractive one and one is easily attracted by the picture. This seems to be the auditorium of the university. The benches in the auditorium are very nice and well-arranged and the capacity for candidates is larger. Students are usually attracted by such features of the universities. The logo of the university can also be seen in the screenshot. The logo contains the phrase "Leaders with Vision". The university aim is to produce leaders with a strong vision. This is the persuasive use of language. Students' attention is caught by the phrase because everyone wants to become a leader and they think the university can help them become a good leader. The phrase is made up of three words. Two of the words are the content words are the choice of these two words is not made randomly. Rather the two words are selected for a purpose. Implicit ideologies are behind these choices. 


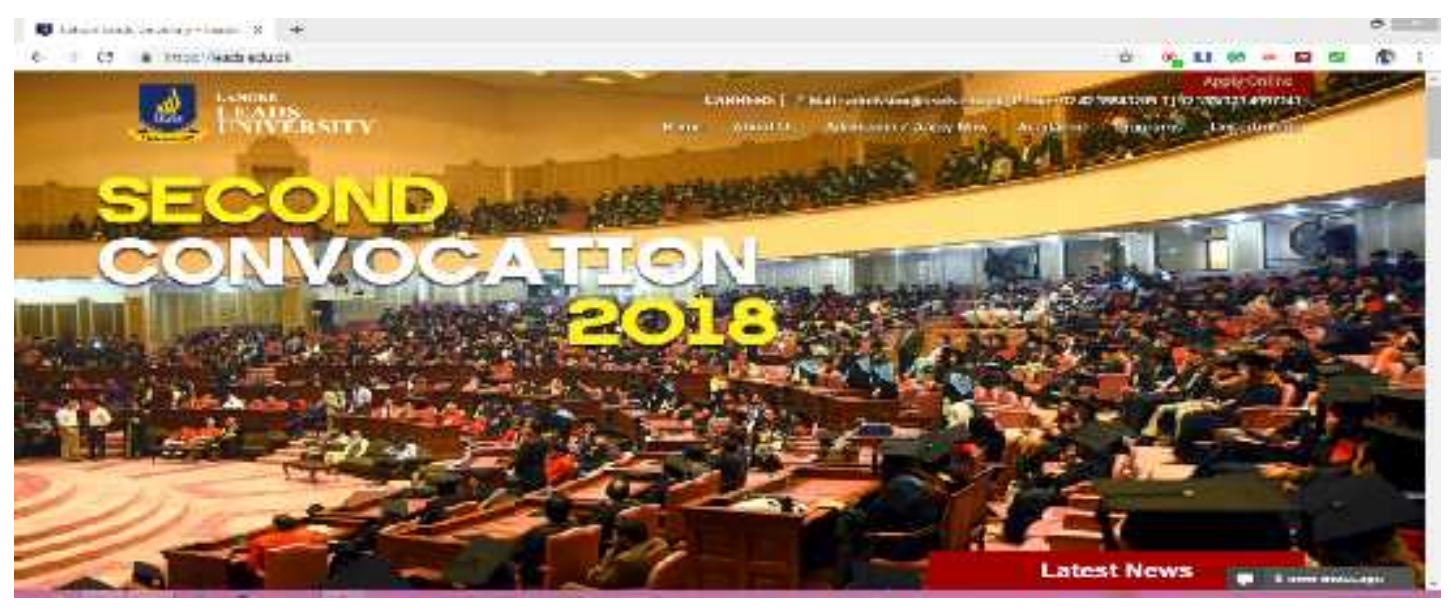

The discussion generated by the analysis of the above-mentioned websites and pictures of the universities included in this study is that these use universities make calculated choice of vocabulary, pictures and grammar for loading them with their implicit ideologies. In accordance with the age and disposition of young students, educational organizations of the private sector design such type of website homepages that normally highlight pictures of beautiful young female students clad in fashionable dress, to attract male students who are commonly high in number inside Pakistan; they use attractive buildings to establish the students' trust in the high quality of education of the institutions; they use pictures of luxuriant lawns to give a feeling of escape and enjoyment inside of the boring and monotonous environment of inside classes, smiling faces of students of both sexes sitting together, indicating ease, comfort, and enjoyment, photos showing students throwing their hoods upwards in jubilation of getting their degrees.

According to Fairclough (1992), language is the product of power and identity is the product of language use. Identity is created when language is used. Identity is not permanent. It is fragmented. It is not static."Identity is used in this book to describe the way individuals and groups define them-selves and are defined by others on the basis of race, ethnicity, religion, language, and culture" (Deng 1995). Identity changes every now and then. The language used by the different university creates the identity of that university. The university not only creates the identity of self but it also creates the identity of the other universities and of the visitors of the website. In the above screenshots taken from the website homepages of different universities, the universities have used different words, sentences and pictures. These words, sentences and pictures create the identities of the universities. If a university has given the pictures of female on the homepage of the university, it shows that the university offers co-education. In return, this also creates the identity of the visitors as subjects who are interested in females that is why the pictures of females are uploaded on the website. Identities are "relatively stable, role-specific understandings and expectations about self" (Wendt 1992). 
Fairclough (1992) says that when discourse is produced, certain assumptions and expectations are taken for granted and, in the same way, in the interpretation of the text, some assumptions and interpretations are taken for granted. The universities have produced their texts and discourse in the form of website homepages. People visit these websites of the universities and interpret it in their own way according to their own understanding. There are some differences in the interpretation of the discourse of these universities on individual level but the basic method and way of the interpretation of the text is the same. Fairclough says that language is a social practice. Language is produced by taking into account the existing social structures, institutional structures and discourse structures and in the same way, language is interpreted by keeping in view these structures. Like Fairclough, Halliday (1994) is another supporter of the relation between society and discourse. He believes that language is "social act".

Language is not produced randomly. Language is produced after the complex process of selection and rejection. In the above screenshot, it was seen that different universities had chosen different vocabulary, phrases, clauses, sentences, colors and pictures to represent themselves and create their identity. Different choices are always available to language producers and they select words that can best serve their purpose. Saussure (1915) says that meanings are created in the choices that we make. Similarly, Fowler et al. (1979) points out that the choice of grammar and vocabulary for subjects is not arbitrary but ideologically based. No one selects a linguistic term randomly. After complex process of selection and rejection, one makes a choice and there are always hidden ideologies behind it. Fairclough (1992) pointed out that implicit ideologies work behind every discourse. The universities have produced discourses and there are implicit ideologies behind their discourses and through these implicit ideologies, they want to achieve their objectives. Through these implicit ideologies they want to exercise their power over the public. These ideologies are kept hidden by the universities because these ideologies only work when they are implicit. These ideologies become common sense after the process of naturalization. These common sense assumptions are then taken for granted by the language interpreters and they do not even notice that through these common sense assumptions, power is being exercised over them. People accept what is being presented and delivered to them blindly. In the case of these university websites, people visit them and they are easily impressed by the university websites and they take admission in the university. They do not realize that the language is written to persuade us and they do not think of the implicit objectives of the universities.

\section{Conclusion}

Language is the product of power and identity is always in a flux and comes into being when language is used. The universities under investigation were shown to create identity not only of their selves but also of other universities and of the visitors of their websites. Language being a social practice, both its production and 
interpretation are done by taking into account social structures, institutional structures and discourse structures that are present around. Choice of words is always laden with meaning, as meaning can be created and manipulated through it. Universities of the private sector under investigation manipulated the choice of language in their favor and created their identity. The websites of private universities make a calculated choice of vocabulary, pictures and grammar for loading them with their ideologies, in an implicit manner for better results. Through naturalization, these implicit ideologies become common sense assumptions which are taken for granted by interpreters, who unaware of being subjected to the exercise of power over them, subscribe to them. In the process, they imperceptibly get deceived by letting themselves to be influenced by the persuasive language, without carrying out critical analysis of the hidden ideologies. 


\section{References}

Bonnardel, N., Piolat, A., \& Le Bigot, L. (2011). The impact of colour on website appeal and users' cognitive processes. Displays, 32(2),69-80.

Deng, F. M. (1995). War of visions: Conflict of identities in the Sudan. Washington, DC: Brookings.

Fairclough, N. (1992). Discourse and social change. Cambridge: Polity Press

Fowler, R. B., Hodge, G. Kress, T., \& Trew, T. (1979). Language and control. London: Routledge.

Halliday, M. A. K. (1994). Introduction to functional grammar. London: Edward Arnold.

De Saussure, F. (1915). Cour de linguistic general (course in general linguistics), translated by Wade Baskin. New York, Toronto and London: McGraw Hill Book Company.

Turhan, B. (2017). Critical discourse analysis of advertising: Implications for language teacher education. International Journal of Languages' Education, 1, 213226.

Van Dijk, T. A. (1985). The handbook of discourse analysis. London: Academic Press.

Weideman, M. (2013). Comparative analysis of homepage website visibility and academic rankings for UK universities. Information Research: An International Electronic Journal, 18(4), 1-19.

Weinberg, B. D. (2000). Don't keep your internet customers waiting too long at the (virtual) front door. Journal of Interactive Marketing, 14(1), 30-39.

Wendt, A. (1992). Anarchy is what states make of it: the social construction of power politics. International organization, 46(2), 391-425.

Wodak, R. (1996). Disorders of discourse. London: Longman. 